\title{
Medical importance of Datura fastuosa (syn: Datura metel) and Datura stramonium - A review
}

\author{
Prof Dr Ali Esmail Al-Snafi \\ Department of Pharmacology, College of Medicine, Thi qar University, Iraq.
}

\begin{abstract}
The preliminary phytochemical investigation was performed on methanolic and hydroalcoholic extract of Datura fastuosa (syn: Datura metel) revealed the presence of alkaloids, tannins, cardiac glycosides, flavonoids, carbohydrates, amino acids and phenolic compounds, while, phytochemical analysis of Datura stramonium showed that it contained alkaloids, saponins, tannins, steroids, flavonoids, phenols and glycosides. The previous pharmacological studies of Datura fastuosa showed that it possessed antimicrobial insecticidal, antidiabetic, cytotoxic, antioxidant, antiinflammatory, analgesic, antipyretic, neurological, wound healing, reproductive and antispasmodic, while Datura stramonium exerted Antiepileptic, Anti-asthmatic, analgesic, antioxidant, antimicrobial, insecticidal, repellent and organophosphate protective effects. The current review highlights the chemical constituents and pharmacological effects of Datura fastuosa and Datura stramonium.
\end{abstract}

Keywords: chemical constituents, pharmacology, Datura fastuosa, Datura metel, Datura stramonium.

\section{INTRODUCTION:}

The World Health Organization (WHO) estimates that 4 billion people, 80 percent of the world population, presently use herbal medicine for some aspect of primary health care [1]. Plants generally produce many secondary metabolites which were constituted an important source of many pharmaceutical drugs. Many previous reviews revealed the wide range of the pharmacological and therapeutic effects of medicinal plants [270].The preliminary phytochemical investigation was performed on methanolic and hydroalcoholic extract of Datura fastuosa (syn: Datura metel) revealed the presence of alkaloids, tannins, cardiac glycosides, flavonoids, carbohydrates, amino acids and phenolic compounds, while, phytochemical analysis of Datura stramonium showed that it contained alkaloids, saponins, tannins, steroids, flavonoids, phenols and glycosides. The previous pharmacological studies of Datura fastuosa showed that it possessed antimicrobial insecticidal, antidiabetic, cytotoxic, antioxidant, antiinflammatory, analgesic, antipyretic, neurological, wound healing, reproductive and antispasmodic, while Datura stramonium exerted Antiepileptic, Anti-asthmatic, analgesic, antioxidant, antimicrobial, insecticidal, repellent and organophosphate protective effects. The current review will highlight the chemical constituents and pharmacological effects of Datura fastuosa and Datura stramonium.

\section{DATURA FASTUOSA (SYN: DATURA METEL)}

Synonyms: Brugmansia waymannii Paxton, Datura aegyptiaca Vis., Datura alba Rumph. ex Nees, Datura alba F.Muell., Datura alba var. africana Mattei, Datura bojeri Delile, Datura chlorantha Hook., Datura cornucopia auct., Datura dubia Rich., Datura dubia Bianca ex Tod., Datura fastuosa L., Datura fastuosa var. alba Bernh., Datura fastuosa var. flaviflora O. E. Schulz ex O. C. Schmidt, Datura fastuosa var. glabra Bernh., Datura fastuosa var. parviflora Nees, Datura fastuosa var. rubra Bernh., Datura fastuosa var. tuberculata Bernh., Datura fruticosa Hornem., Datura humilis Desf., Datura hummatu Bernh., Datura laevis Schkuhr, Datura metel var. dentata Schltdl. \& Cham., Datura metel var. fastuosa (L.) Saff., Datura metel var. flaviflora (O.E.Schulz) Moldenke, Datura metel var. muricata (Link) Danert, Datura metel f. pleniflora O. Deg., Datura muricata Link, Datura nanakii Pandeya \& A. B. Bhatt, Datura nigra Hassk., Datura nilhummatu Dunal, Datura timoriensis Zipp. ex Span., Stramonium datura Noronha, Stramonium fastuosum Moench, Stramonium globosum Bubani, Stramonium infernale Noronha and Stramonium metel Moench [71].

\section{TAXONOMIC CLASSIFICATION:}

Kingdom: Plantae; Division: Magnoliophyta; Subdivision: Angiospermae; Class: Magnoliopsida; Subclass: Asterids; Order: Solanales; Family: Solanaceae; Genus: Datura; Species: Datura fastuosa (Datura metel) [72].

\section{COMMON NAMES:}

Arabic: tatura, joz mashel, joz mathel; Chinese: yang jin hua; English: downy thorn-apple, Hindu datura, Hindu thorn-apple, hoary thorn-apple, horn-of-plenty, metel, purple thorn-apple; Hindi: sada dhatura; Korean: huindogmalpul; Portuguese: burbiaca; Spanish: burladora; Swedish: indisk spikklubba [73]. Distribution: 
The possible origin is west Indies or America, now it is distributed in Asia in tropical, warm temperature regions [73].

\section{DESCRIPTION:}

Herbs annual, 0.5-1.5 m tall, glabrescent. Stems often dark violet. Petiole 2-6 cm; leaf blade ovate or broadly ovate, $5-20 \times 4-15 \mathrm{~cm}$, membranous, glabrescent, base truncate or cuneate, asymmetrical, margin irregularly sinuate-dentate, lobed, or entire, apex acuminate; veins 4-6 pairs. Flowers erect. Pedicel ca. $1 \mathrm{~cm}$. Calyx tubular, 4-9 cm. Corolla white, yellowish, or pale purple, funnelform, sometimes doubled or tripled, 14-20 cm; limb 6-10 cm in diam.; lobes elongate. Anthers 1-1.2 cm. Capsules deflexed, subglobose, ca. $3 \mathrm{~cm}$ in diam., tuberculate, irregularly 4-valved, subtended by remnants of persistent calyx. Seeds pale brown, reniform-discoid, ca. $3 \mathrm{~mm}$ in diameter [74].

\section{TRADITIONAL USES:}

The dried leaves, flowers and roots were used as narcotic, antispasmodic, antitussive, bronchodilator, anti-asthmatic and as hallucinogenic. The plant was also used in diarrhea, skin diseases, epilepsy, hysteria, rheumatic pains, hemorrhoids, painful menstruation, skin ulcers, wounds and burns. In ayurveda, the plant was considered bitter, acrid, astringent, germicide, anodyne, antiseptic, antiphlogistic, narcotic and sedative [75-76].

Parts used medicinally: Seeds, flower, root bark and leaves[75-76].

\section{PHYSICOCHEMICAL CHARACTERISTICS:}

Physicochemical evaluation of dried seeds of Datura fastuosa revealed that the plant contained otal ash $5.6 \% \mathrm{w} / \mathrm{w}$, water soluble ash $4.5 \% \mathrm{w} / \mathrm{w}$, water soluble extractive $26.35 \mathrm{mg} / \mathrm{gm}$, foaming index 18.18 , swelling index $2.6 \mathrm{ml} / \mathrm{g}$, moisture content $1.4 \mathrm{ml}$, crude fibre content $17.5 \% \mathrm{w} / \mathrm{w}$ and loss on drying $390 \mathrm{mg}$ [77].

\section{CHEMICAL CONSTITUENTS:}

The preliminary phytochemical investigation was performed on methanolic and hydroalcoholic extract of Datura fastuosa dried seeds revealed the presence of alkaloids, tannins, cardiac glycosides, flavonoids, carbohydrates, amino acids and phenolic compounds [77].The proximate analysis showed that the seeds of the plant contained fat $(14.72 \%)$, carbohydrate $(51.22 \%)$, protein $(20.73 \%)$, moisture $(4.63 \%)$, ash content $(5.14 \%)$, total sugar $(5.63 \%)$, reducing sugar $(2.65 \%)$, crude firbre $(17.35 \%)$ and trace elements $(\mathrm{mg} / 100 \mathrm{gm})$ : calcium 174.0, phosphorous 690.0 , potassium 0.50 , sodium 0.085 , Iron 16.8 , zinc 2.63 , copper 6.9 and magnesium 390.0. Total saturated fatty acids was $18.03 \%$ and total unsaturated fatty acids was $81.74 \%$, mono-unsaturted fatty acids $27.49 \%$, poly - unsaturted fatty acids $54.25 \%$. Fatty acid profile consisted of palmitic acid $15.31 \%$, stearic acid 2.72 5, oleic acid 25.97, linoleic acid 54.25\%, and palmitolic acid $1.52 \%$ [78]. The essential oil from different parts of Datura metel. were extracted using hydrodistillation and analysis by GC-MS. The main components of flowers were ketone $(23.61 \%)$ and ethyl palmitate $(15.84 \%)$. The main components of leaves were ketone (18.84\%) and phytol (18.71\%). Ketone (39.45\%) and phytol (31.32\%) were the major components of petioles. Palmitic acid $(30.60 \%)$ and ethyl linoleate $(21.56 \%)$ were the major components of seeds. The major ingredient of roots was palmitic acid $(52.61 \%)$. The main ingredients of the stems were palmitic acid $(38.38 \%)$ and ethyl linoleate (17.38\%) [79]. Tropane alkaloids are a group of more than 200 compounds best known for their occurrence in the family Solanaceae comprising over 100 genera and 3000 plant species. Tropane alkaloids characterized by a two-ringed structure with a pyrrolidine and a piperidine ring sharing a single nitrogen atom and two carbon atoms. The amino group, typical for all alkaloids, is in most cases methylated. The most important natural tropane alkaloids are (-)-hyoscyamine and (-)-scopolamine (also known as hyoscine). High concentrations of these alkaloids have been found particularly in Datura species. Hyoscine [(-)-Scopolamine] represented the main tropane alkaloid in Datura fastuosa (Datura metel) [80]. However, the plant contained alkaloids, hyosyamine, hyoscine and atropine. The total alkaloid content of the leaves was $0.426 \%$ which were mainly atropine. The seeds contained $0.426 \%$ and the flower contained $0.43 \%$ hyoscyamine. Scopolamine and atropine contents in the whole plant of the plant increased gradually with the progress of developmental growth, and were most pronounced when the plant was at the end of its reproductive stage. The highest percentage of scopolamine accumulation in the root was after 16 weeks. The root was the organ which often accumulated higher amounts of atropine. The aerial parts, if compared with the root of the plant, usually accumulated relatively higher amounts of scopolamine and relatively lower amounts of atropine [81]. The leaves and flowers of Datura fastuosa yielded many withanolides included withafastuosins A, B, C and E; dmetelins A-D; baimantuoluoline A, B and C and withametelin [82-84]. Three new withanolide compounds named baimantuoluoline $\mathrm{A}, \mathrm{B}$, and $\mathrm{C}$ and the withafastuosin $\mathrm{D}, \mathrm{E}$ and $\mathrm{F}$ and withametelin $\mathrm{C}$ were isolated from different parts of the plant $[83,85-86]$.

However, chemical investigation of a methanol extract of the flowers of Datura metel has led to the isolation of 10 new withanolides, withametelins I-P. Daturafolisides A-I, (22R)-27-hydroxy-7 $\alpha$-methoxy-1-oxowitha-3,5,24- 
trienolide-27-O- $\beta$-d-gluco-pyranoside, daturataturin A, daturametelin $\mathrm{J}$, daturataurin $\mathrm{B}$, baimantuoluoside $\mathrm{B}$ and 12-deoxywithastramonolide were isolated from the leaves of the plant [87-88]. Four compounds were detected in methanolic extracts of flower, including cis-2- nitro-4-t-butylcyclohexanone (36.54\%), acetic acid, trifluoro-, 2,2-dimethylpropyl ester (31.97\%), 4-trifluoroacetoxyoctane (19.28\%) and 1,4-cyclohexadiene, 1-methyl(12.22\%) [89]. Phytochemical investigation of the $50 \%$ ethanol fraction of macroporous resin of the flower of the plant led to the isolation of yangjinhualine A and five megastigmane sesquiterpenes [90]. Isofraxidin, scopatone, daturadiol ,1,4-benzenediol, arenarine D, vanillin, N-trans-feruloyl-tyramine, scopoletin , G-sitosterol and hyoscyamilactol were isolated from the seeds of Datura metel from Xinjiang Province [91].

The amount of total phenolic content (TPC) and total flavonoid contents (TPC) were analysed. The highest TPC was determined in methanolic extracts of seed $(268.6 \mu \mathrm{g}$ of gallic acid equivalence/ $\mathrm{mg}$ of dry plant material) and the highest TPC was determined in fruit pulp $(8.84 \mu \mathrm{g}$ of quercetin equivalence/mg dry plant material) [92].

\section{PHARMACOLOGICAL EFFECTS: Antimicrobial effects:}

The antimicrobial effect of hydro-alcoholic and methanolic seed extracts of Datura fastuosa was evaluated against three clinical bacterial strains (Escherichia coli, Staphylococcus aureus and Bacillus subtilis) and two clinical fungal strains (Candida allbicans and Aspergillus niger) by tube dilution method. Both plant extracts were active against the tested microorganisms. The methanolic extract of Datura fastuosa inhibited E. coli effectively with minimum bactericidal concentration (MBC) of $25 \mu \mathrm{g} / \mathrm{ml}$. The hydroalcoholic extract of Datura fastuosa seeds was found to be more potent in terms of its bactericidal concentration against $B$. subtilis with both minimum inhibitory concentration (MIC) and MBC values of $25 \mu \mathrm{g} / \mathrm{ml}$. Methanolic extract was found to be more efficient in inhibiting $S$. aureus with $\mathrm{MIC}$ of $12.5 \mu \mathrm{g} / \mathrm{ml}$ [93]. A new antibacterial agent $5^{1}, 7^{l}$ dimethyl $6^{l}$ - hydroxy $3^{l}$, phenyl 3 a - amine $\mathrm{b}$ - yne sitosterol was isolated from the plant leaves. It displayed antibacterial activity against Staphylococcus aureus, Pseudomonas aeruginosa, Proteus mirabis, Solmonella typhi, Bacillus subtilis and Klebsiella pneumonia but could not inhibit Escherichia coli [85]. The antipathogenic effect of carbon tetrachloride, benzene and chloroform extract crude extracts of Datura leaf extract was studied against Enterobacter species. Carbon tetra chloride and benzene extracts $(1000 \mu \mathrm{g} / \mathrm{ml})$ of the leaves of Datura metel showed excellent activity on comparing with that of standard drug, ciprofloxacin $(100 \mu \mathrm{g} / \mathrm{ml})$ [94].The hexane, chloroform, acetone and methanolic fractions of the plant. were investigated for antifungal properties using pathogenic species of Aspergillus (A. fumigatus, A. flavus and A. niger). The chloroform fraction was found to be endowed with antifungal activity. The minimum inhibitory concentration (MIC) of chloroform fraction was $625.0 \mathrm{microg} / \mathrm{ml}$ against all the three species of Aspergillus, by microbroth dilution and percent spore germination inhibition assays. The MIC by disc diffusion assay was observed to be $12.5 \mathrm{microg} / \mathrm{disc}$. The chloroform fraction of the pant, when investigated for potency, turned to be 9.2 times less active than amphotericin B [95]. 2beta-(3,4-dimethyl-2,5-dihydro-1H-pyrrol-2-yl)-1'-methylethyl pentanoate isolated from the leaves of Datura metel was endowed with antifungal activity and its MIC was found to be $87.5 \mathrm{microg} / \mathrm{ml}$ [96].The antiviral activity of atropine was evaluated by plaque reduction test against Herpes Simplex virus, Influenza virus, New Castle Disease virus, Sindbis, Vaccinia, Adenovirus and Japanese encephaitis virus. Viruses were cultivated on primary chick embryo (CE), HeLa S3, primary monkey kidney cells (MK). Atropine inhibited only the growth of enveloped viruses independent of the nucleic acid content of the virus. It also blocked the glycosylaton of viral proteins of Herpes virus and hence the production of new virions. Virions formed in the presence of atropine were non infectious [97-98].

\section{Insecticidal effects:}

Different percentage of methanolic extract of Datura metel seeds were tested against Helicoverpa armigera (Hubner). The 1.5 and $2 \%$ of methanolic extract showed significant adverse effects on larval survival, weight and duration, pupal period, $\%$ of pupation and adult emergence [99].

\section{Antiinflammatory, analgesic and antipyretic effects:}

The anti-inflammatory activity of ethanolic and ethyl acetate extracts of root part of Datura fastuosa $(50,100,150,200 \mathrm{mg} / \mathrm{kg}$ orally) was evaluated using carrageenan induced rat paw edema. Indomethacin was used as a standard drug. All extracts showed significant activity at $200 \mathrm{mg} / \mathrm{kg}$ dose as compared to indomethacin $(10 \mathrm{mg} / \mathrm{kg})$. The percentage inhibition was calculated for all doses of different extracts. Ethanolic extract possessed significant anti-inflammatory activity [100].Fifteen compounds isolated from the leaves of Datura metel were evaluated for in vitro anti-inflammatory potential using LPS-stimulated RAW 264.7 murine macrophages. Among them, compounds daturafolisides A and B, baimantuoluoside B and 12 deoxywithastramonolide exhibited significant inhibition of nitrite production with $\mathrm{IC}_{50}$ of $20.9,17.7$, 17.8, and $18.4 \mu \mathrm{M}$. Compounds daturafolisides $\mathrm{C}, \mathrm{D}$ and $\mathrm{F}$ and daturataurin $\mathrm{B}$ presented moderate inhibitory activities 
with $\mathrm{IC}_{50}$ of 59.0, 52.8, 71.2, and 53.1 $\mu \mathrm{M}$ [88]. Dmetelins A-D, and 7 $\alpha, 27$-dihydroxy-1-oxo-witha-2,5,24trienolide isolated from the leaves of Datura metel were evaluated for their inhibitory effects on lipopolysaccharide (LPS)-induced nitric oxide (NO) production in RAW264.7 cells. Compounds, dmetelin A, D and 7 2,27 -dihydroxy-1-oxo-witha-2,5,24-trienolide, showed significant inhibitory activities, and compounds dmetelin $\mathrm{B}$ and $\mathrm{C}$ showed moderate inhibitory activities with $\mathrm{IC}_{50}$ values of $17.8,11.6,14.9,33.3$ and $28.6 \mu \mathrm{M}$, respectively [84].The aqueous extracts of Datura fastuosa leaves and seeds were evaluated for the analgesic effect on acetic acid-induced writhing and hot plate reaction in mice. The results revealed that Datura fastuosa leaves and seeds extracts at doses of 400 and $800 \mathrm{mg} / \mathrm{kg}$ orally induced analgesic effects. The analgesic activity of leaf extract was reduced by naloxone but not that of seed extract [101]. The leaves extract of Datura fastuosa exhibited analgesic effect in acetic acid test with tolerance phenomenon, but not by the seed extracts. Only the leaf extract reduced rectal temperature, apomorphine hypothermia and increased water intake [102].

\section{Antispasmodic and spasmogenic effects:}

The effect of the plant leaf and root extracts, scopolamine and acetylcholine was studied on isolated smooth muscle preparations. The leaf extract and scopolamine showed antispasmodic effects, whereas root extract and acetylcholine caused contraction of the isolated rat uterus and rectum whole muscle. The results indicated that the plant contained antispasmodic and spasmogenic constituents [103].

\section{Neurological effects:}

The neuropsychopharmacological effects of aqueous extracts of leaves and seeds of Datura fastuosa, were studied in rat and mice. The leaf and seed extracts at doses of 400 and $800 \mathrm{mg} / \mathrm{kg}$ increased motor activity, reduced slightly the duration of barbituric sleeping, antagonized catalepsy and ptosis induced by haloperidol and the immobility induced by forced swimming. The results also showed that, Datura fastuosa has some antidepressant profile at low doses [102].The potential oral anaesthetic effect of methanolic crude extract of Datura metel was studied in dogs. The extract administered orally to dogs at a dose rate of $0.6,1.2,1.5,2$ and $2.4 \mathrm{~g} / \mathrm{kg}$ respectively during establishment of a suitable pilot oral anaesthetic doses, showed a graded dose response relationship. The extract at an oral dose of $2.4 \mathrm{~g} / \mathrm{kg}$ induced surgical anaesthesia in dogs with increased heart and respiratory rates (107 to $205 \mathrm{bpm}$ and 36.33 to $41.33 \mathrm{cpm}$ ) respectively, normal rectal temperature $\left(37.83^{\circ} \mathrm{C}\right)$, adequate tissue perfusion, good muscle relaxation but poor analgesia. The dogs recovered without any complications. The study revealed that the seed extract of Datura metel was relatively safe, induced sleep similar to that of thiopentone sodium anaesthesia with good anaesthetic indices [104].25 g/kg of methanolic crude extract induced behavioural sleep patterns (EEG) similar to that of thiopental in rats [105]. The activity of ethanolic seed extract of Datura metel on Nissl substances, astrocytes, axonal and neuronal integrity of the medial prefrontal cortex (mPFC) was studied in rats. Extract was given 100 and $200 \mathrm{mg} / \mathrm{kg}$ bw for 14 days. The results revealed that Datura metel was deleterious to the health of Wistar rats at a dose-dependent rate as observed in its actions on the medial prefrontal cortex at $100 \mathrm{mg} / \mathrm{kg}$ bw and $200 \mathrm{mg} / \mathrm{kg} \mathrm{bw}$. The histological study of the treated Wistar rats exhibited features of disoriented neuronal integrity such as, chromatolysis, reduced protein synthesis due to loss of Nissl substances and nuclei, neuronal loss as well as axonal injuries [106].

\section{Antioxidant effect:}

Hydroalcoholic and methanolic seed extracts of Datura fastuosa were evaluated for antioxidant potential, total antioxidant capacity, total amount of phenolic content, total flavonoid content, total flavonols and total proanthocyanidines contents. The $\mathrm{IC}_{50}$ value using DPPH model for methanolic extract of Datura fastuosa was $28.34 \mu \mathrm{g} / \mathrm{ml}$ and for hydroalcoholic extract was $25.78 \mu \mathrm{g} / \mathrm{ml}$. The values of total antioxidant capacity, total amount of phenolic content, total flavonoid content, total flavonols and total proanthocyanidines content for methanolic extract of Datura fastuosa were found to be $6.83 \mathrm{mg} / \mathrm{g}, 9.97 \mathrm{mg} / \mathrm{g}, 6.34 \mathrm{mg} / \mathrm{g}, 5.37 \mathrm{mg} / \mathrm{g}$ and 1.42 $\mathrm{mg} / \mathrm{g}$ of plant extract respectively and for hydroalcoholic extract, the values for the same parameters were 7.44 $\mathrm{mg} / \mathrm{g}, 6.88 \mathrm{mg} / \mathrm{g}, 9.35 \mathrm{mg} / \mathrm{g}, 5.36 \mathrm{mg} / \mathrm{g}$ and $0.88 \mathrm{mg} / \mathrm{g}$ respectively [93].The antioxidant activity of different solvent extracts from the leaves of Datura metel was tested by DPPH scavenging activity, hydroxyl radical scavenging activity, reducing power assay, and $\beta$-carotene bleaching activity. The antioxidant activity was performed at four concentrations ranging from 25-100 $\mathrm{mg} / \mathrm{ml}$. Chloroform extract exhibited highest concentration dependent antioxidant activity [107]. In vitro antioxidant activity of the extract was tested by 2, 2diphenyl-1-picrylhydrazyl radical scavenging method. A positive correlation was recorded between the phenolic and flavanoid content of the Datura metel extracts and the free radical scavenging activities [92].

\section{Cytotoxic effect:}

Chemical investigation of a methanol extract of the flowers of Datura metel has led to isolation of 10 new withanolides, withametelins I-P. Four of 10 withanolides exhibited cytotoxic activities against A549 (lung), 
BGC-823 (gastric), and $\mathrm{K} 562$ (leukemia) cancer cell lines, with $\mathrm{IC}_{50}$ values ranging from 0.05 to 3.5 microM [87].The in vitro cytotoxicity assay was performed in vero cell line by 3-(4,5-dimethylthiazol-2-yl)-2,5diphenyltetrazolium bromide assay method. The $\mathrm{IC}_{50}$ of a methanolic cold extract of datura fruit was found to be $3 \mathrm{mg} / \mathrm{ml}$ against vero cell line [92].The cytotoxicity of withanolides isolated from Datura metel was evaluated against human lung carcinoma cells (A549) and human colorectal adenocarcinoma cells (DLD-1), respectively. $12 \alpha$-hydroxydaturametelin exhibited cytotoxicity against A549 and DLD-1 cell lines, with IC $_{50}$ values of 7 and $2.0 \mu \mathrm{M}$, respectively. However, Two compounds possessed higher cytotoxic effects against DLD-1 cells with $\mathrm{IC}_{50}$ values of 0.6 and $0.7 \mu \mathrm{M}$ respectiely. Both compounds blocked the cell cycle in the S-phase and induced apoptosis [108].The roots and stems showed inhibitory effects against HepG-2 with $\mathrm{IC}_{50}$ levels of 613.88 and $341.12 \mathrm{mg} / \mathrm{l}$. The leaves and roots showed inhibitory effects against HeLa with $\mathrm{IC}_{50}$ levels of 267.76 and $348.35 \mathrm{mg} / \mathrm{l}$. All the six parts possessed inhibitory effects against SGC-7901 cell lines [79].

\section{Wound healing effects:}

The ethanolic extract of Datura fastuosa was evaluated for wound healing activity in Wistar albino rats using excision wound model. The extract was formulated as an ointment at two concentrations $(5 \%$ and $10 \%$ $\mathrm{w} / \mathrm{w})$. Nitofurazone ointment $(0.2 \% \mathrm{w} / \mathrm{w})$ was used as standard. The parameters utilized for evaluation were percentage wound closure, mean epithelization time, hydroxyproline, DNA and protein level. The histopathological studies were also carried out on wound tissue. The result revealed that $10 \% \mathrm{w} / \mathrm{w}$ Datura fastuosa ointment exhibited significant wound healing activity comparable to that of the standard [109].

\section{Antidiabetic effect:}

The seed powder of the plant was tested for its hypoglycemic activity in normal and alloxaninduced diabetic rats. 25,50 and $75 \mathrm{mg} / \mathrm{kg}$, of the seed powder orally produced significant reduction in blood glucose at the $8 \mathrm{~h}$ in both normal and diabetic rats. The effect was found to be dose dependent [110].

Xanthine oxidase inhibitory activity:

The aqueous, methanol-water mixture and methanolic extract of Datura metel were evaluated for xanthine oxidase inhibitory activity at $100 \mathrm{microg} / \mathrm{ml}$. The methanolic extracts of Datura metel showed more than $50 \%$ inhibition compared with the standard antigout drug, allopurinol, which showed $93.21 \%$ inhibition at $100 \mu \mathrm{g} / \mathrm{ml}$ concentrations [111].

\section{Reproductive effects:}

The antifertility activity of the acetone extracts of Datura metal was evaluated in female albino mouse. The crude acetone extract of Datura metel seeds were given orally to the female mouse in the concentration of $0.5 \%, 1 \%$ and $2 \%$ respectively. After 15 day of treatment the female mouse was mated with the normal male mouse. After 10 days of mating they were dissected to observe the number of implantation sites in the uterine horns. The results revealed that $2 \%$ seed extracts caused $100 \%$ anti-implantation activity followed by $1 \%$ and $0.5 \%$ seed extracts which caused $40 \%$ and $80 \%$ anti implantation activity respectively. The authors concluded that the seed extracts of Datura metel may be recommended as a good source of antifertility compounds with minimal side effects [112].The effect alcoholic extract of Datura fastuolsa ( 2,4 and $6 \mathrm{mg} / \mathrm{kg}$, for 7 weeks) on the fertility was studied in rat males. The results showed that the extract induced significant decrease in concentrations of sperm and normal sperm in all the concentrations in comparing with control group. They also significantly decreased serum levels of testosterone, $\mathrm{LH}$ and $\mathrm{FSH}$, and weights of the testes and epididymis in the treated groups, The percentage of occurance of pregnancy was also significantly decreased [113].

\section{Toxicity and side effects:}

Datura fastuosa was found to be safe up to dosage of $2000 \mathrm{mg} / \mathrm{kg}$ body weight with no symptoms of toxicity or mortality $[72,111]$. The aqueous extracts of leaves and seeds of of Datura fastuosa were well tolerated by rats. No mortality was observed up to $3200 \mathrm{mg} / \mathrm{kg}$ [102].The methanolic extract was relatively safe since when administered at the highest dose $(5000 \mathrm{mg} / \mathrm{kg})$ to mice, it produced no sign of toxicity and no death was recorded [104].However, all parts of Datura were poisonous because of the presence of toxic tropane anticholinergic alkaloids which caused neural toxicity. The signs of toxicity were anticolinergic toxic effects including acute confusion, fever, tachycardia, hot flushed dry skin, dilated pupils, dry mouth, urinary retention, hallucinations, headache, delirium, rapid and weak pulse, convulsions, coma and death [114-115].

Toxicological assessment shown that the extract of Datura metel seed induced deleterious effect on the visual cortex and frontal cortex of the brain in rats [116-117]. Histological evaluation of the organs showed decrease in organ weight, circulatory disturbance, necrotic changes in the liver architecture with increase of serum alkaline phosphatase, serum glutamic-oxaloacetic transaminase and glutamyl pyruvic transaminase in liver and heart [118]. 


\section{DATURA FASTUOSA (SYN: DATURA METEL)}

\section{SYNONYMS:}

Datura bernhardii Lundstr., Datura bertolonii Parl. ex Guss., Datura cabanesii P. Fourn., Datura capensis Bernh., Datura ferocissima Cabanès \& P. Fourn., Datura ferocissima Cabanès \& P.Fourn., Datura ferox Nees, Datura hybrida Ten., Datura inermis Juss. ex Jacq., Datura laevis L.f., Datura loricata Sieber ex Bernh., Datura lurida Salisb., Datura microcarpa Godr., Datura muricata Godr., Datura parviflora Salisb., Datura praecox Godr, Datura pseudo stramonium Sieber ex Bernh, Datura stramonium var. canescens Roxb., Datura stramonium var. chalybaea W. D. J. Koch, Datura stramonium var. gordonii Danert, Datura stramonium f. inermis (Juss. ex Jacq.) Hupke, Datura stramonium var. inermis (Juss. ex Jacq.) Fernald, Datura stramonium var. stramonium, Datura stramonium var. tatula (L.) Decne., Datura stramonium f. tatula (L.) B. Boivin, Datura stramonium var. tatula (L.) Torr., Datura tatula L., Datura wallichii Dunal, Stramonium foetidum Scop [119-120].

\section{TAXONOMIC CLASSIFICATION:}

Kingdom: Plantae, Division: Magnoliophyta, Class: Magnoliopsida, Order: Solanales, Family: Solanaceae, Genus: Datura, Species: Datura stramonium [121].

\section{COMMON NAMES}

Afrikaans: gewone stinkblaar; Arabic: tatura, nafer, thagher, banj tatura, tatura shaeka, el-shajara el-muskera, Chinese: man tuo luo; English: common thorn-apple, false castor-oil, jimsonweed, moonflower, purple thorn-apple, thorn-apple; French: datura stramoine, herbe des taupes, pomme épineuse; German: Stechapfel; Italian: indormia, stramonio commune; Portuguese: Estramónio, figueira-do-diabo; Spanish: datura manzana, estramonio, tapa, toloache; Swedish: violspikklubba [119].

\section{DISTRIBUTION}

Datura stramonium originates in the Americas but is now found around the world including the warmer regions of North, Central and South America, Europe, Asia, and Africa [122].

\section{DESCRIPTION}

The plant is an annual and grows to $1.2 \mathrm{~m}$ high. It has a simple or bifurcated, round, erect glabrous stem. The leaves are $20 \mathrm{~cm}$ long, long-petioled, ovate, dentate, glabrous and dark green. The flowers are large, white, solitary, terminal or in the branch bifurcations. The calyx has a long 5-edged and short 5-tipped tube. The corolla is funnel shaped and folded with a short 5-sectioned border. There are 5 free stamens and 1 superior ovary. The fruit is a $5 \mathrm{~cm}$ long 4-valved capsule, which is densely thorny and walnut-sized. The numerous seeds are $3.5 \mathrm{~mm}$ long, flat, reniform and black [123].

\section{TRADITIONAL USES:}

Datura stramonium has long been known for its hallucinogenic and euphoric effects. The weed was dried and smoked for hallucinations and total relaxation [122, 124].

Datura stramonium was used traditionally to treat asthma, gastrointestinal problems, aches, abscesses, arthritis, boils, headaches, hemorroids, rattlesnake bites, sprains, swellings, and tumors. It was used for relieving the pains of rheumatism and sciatica as an ointment, and easing spasms of Parkinsons disease [124]. The juice of the leaves is in warm milk was used to expel intestinal worms including cestodes, seeds with palm oils used externally for insect bites and stings, in Nigeria [125-126]. In Ayurvedic medicine, the plant was used for the treatment of ulcers, wounds, inflammation, sciatica, bruises and swellings, rheumatism, gout, asthma bronchitis and toothache [127].

\section{CH|EMICAL CONSTITUENTS:}

Phytochemical analysis showed that the aqueous and ethanolic extract of the stem-bark of Datura stramonium contained alkaloids, saponins, tannins, steroids, flavonoids, phenols and glycosides [128]. Many amino acids were isolated from the seeds particularly alanine, glutamate, phenylalanine, and tyrosine [129]. The tropane alkaloids were the important anticholinergic alkaloids isolated from Datura stramonium [130].

Production of tropane alkaloids in Datura stramonium plants was found to start from the end of the second week after seed germination. The rates of atropine and scopolamine production were similar $(0.05 \%)$ at this stage. The quantity of alkaloids reached maximum at the end of the tenth week after seed germination, then gradually decreased as the plants entered the generative phase. Alkaloid content depended on the plant part and the stage of 
plant growth. Leaves and capsules showed the highest alkaloid content in the vegetative and generative phases, respectively. Generally the younger parts of plants contained more alkaloids than older ones. Alkaloid content decreased rapidly in leaves in the generative phase. Scopolamine was lowest $(0.013 \%)$ in roots in the vegetative period, and then totally disappeared in the generative period. Atropine occurred in roots in both the vegetative $(0.045 \%)$ and generative $(0.056 \%)$ periods. Stems were rich in atropine $(0.070 \%)$ but poor in scopolamine $(0.023 \%)$ in both stages [131]. The maximum contents of atropine in different parts of Datura stramonium were found in the stems leaves and seeds. The maximum contents of hyoscyamine and scopolamine in different parts of Datura stramonium were found in the stems and leaves of young plants, hyoscyamine being always the predominant component. In the Young plants, the maximum atropine level was recorded in the stems and medium leaves $0.915 \pm 0.015$ and $0.831 \pm 0.014 \mu \mathrm{g} / \mathrm{mg}$ respectively, while in adult plant, the maximum level of atropine was recorded in the flowers and small leaves $0.270 \pm 0.026$ and $0.165 \pm 0.006 \mu \mathrm{g} / \mathrm{mg}$ respectively. On the other hand, in the Young plants, the maximum scopolamine level was recorded in the stems and flowers $0.129 \pm 0.014$ and $0.106 \pm 0.031 \mu \mathrm{g} / \mathrm{mg}$ respectively, while in adult plant, the maximum level of scopolamine was recorded in the seeds and flowers $0.089 \pm 0.010$ and $0.066 \pm 0.004 \mu \mathrm{g} / \mathrm{mg}$ respectively [132-133].

However, sixty-four tropane alkaloids have been detected in Datura stramonium these included: Hygrine; 3á,6â-Ditigloyloxy-7-hydroxytropane; 6-Hydroxyhyoscyamine; Pseudotropine; 3á-Tigloyloxytropane; Hydroxy-6-tigloyloxytropane; Phenyl acetoxytropane; 3-Tigloyloxy-6-(2-methylbutyryloxy) tropane; Hyoscyamine; 3-Tigloyloxy-6-isovaleroyloxy-7- Hydroxytropane; Scopolamine; Tropinone; Scopine; 6Hydroxyacetoxytropane; 3,6-Diacetoxytropane; 3-Tigloxyloxy-6-acetoxytropane; 3-Tigloyloxy-2-methyl butyryl oxytropane; 3á,6â-Ditiglotoxytropane; 3-Acetoxy-6-isobutyryloxytropan; 3-(2-Phenylpropionyloxy) tropane; Littorine; 6-Hydroxy apoatropine; 3â,6â-Ditigloyloxy-7-hydroxytropane; 3-Tropoyloxy-6acetoxytropane; 3,6-Dihydroxytropane; 3â-Tigloyloxytropane; 3-Tigloyloxy-6-propionyloxy-7hydroxytropane; 3á-Apotro-poyloxytropane; Aposcopolamine; 3â,6â-Ditigloyloxytropane; 3-(3'Acetoxytropoyloxy) tropane; 3á-Tigloyloxy-6-hydroxyt ropane; Tropine; 3-Acetoxytropane; 3-Hydroxy-6acetoxytropane; 3-Hydroxy-6-methylbutyryloxytropane; 3-Tigloloxy-6-isobutyryloxytropane; Aponorscopolamine; 7-Hydroxyhyoscyamine; Meteloidine; 3â,6â-Ditigloyloxytropane; 3-phenylacetoxy-6, 7epoxynortropane; 7- hydroxyapoatropine and scopoline [132, 134-135].

The main components of essential oil of Datura stramonium were sterols and their derivatives, and the major constituents were $5 \alpha$-Ergosta-7,22-dien-3.beta.-ol (16.53\%), 3-Hydroxycholestan-5-yl, acetate (14.97\%), and 26,26-Dimethyl-5,24(28)-ergostadien -3ß-ol (10.39\%) [136].

Twelve compounds were isolated by Li et al., from Datura stramonium seeds, they included: N-trans-feruloyl tryptamine, hyoscyamilactol, scopoletin, umckalin, daturaolone, daturadiol, N-trans-ferulicacyl- tyramine, cleomiscosin A, fraxetin, scopolamine, 1-Acetyl-7-hydrox-beta-carbol-ine, 7-hydroxy-beta-carbolinel-propionic acid [137].

\section{PHARMACOLOGICAL EFFECTS: Antiepileptic effect:}

Rats were continuously administered one of three herbal treatments (Scutellaria lateriflora, Gelsemium sempervirens and Datura stramonium) through the water supply for 30 days, one week after the induction of status epilepticus by a single systemic injection of lithium $(3 \mathrm{mEq} / \mathrm{kg})$ and pilocarpine $(30 \mathrm{~g} / \mathrm{kg})$. The numbers of spontaneous seizures per day during a 15 min observation interval were recorded for each rat during the treatment period and during an additional 30 days when only tap water was given. Rats that received a weak solution of the three herbal fluid extracts displayed no seizures during treatment. However, when this treatment was removed, the rats displayed numbers of spontaneous seizures comparable to the controls [138].

\section{Anti-asthmatic effect:}

The specific airway resistance (sRaw) of twelve asthmatic patients with mild airway was measured after inhaling the smoke of one Datura stramonium cigarette. In 11 patients sRaw decreased substantially after the cigarette, the mean maximal decrease being $40 \%$ at the $30^{\text {th }}$ minute. In seven patients the subsequent inhalation of 200 micrograms salbutamol caused no further decrease in sRaw. In the remaining four patients salbutamol induced a larger decrease in sRaw than the cigarette smoke. The inhalation, however, of a synthetic anticholinergic agent (SCH 1000, 600 micrograms) proved as effective as salbutamol in these patients. In one patient the cigarette smoke and SCH 1000 produced only a negligible amount of bronchodilatation whereas [139].

\section{Antimicrobial effects:}

The antimicrobial activity of the aqueous and ethanolic extract of the stem-bark of Datura stramonium was investigation against Staphylococcus aureus, Salmonella typhi, Shigella spp, Eschericia coli, Klebsiella pneumonia and Neisseria gonorrhea. Ethanolic extract showed more antibacterial activity than the aqueous 
extract. It showed antibacterial activity against all the tested bacteria except Neisseria gonorrhea. The aqueous extract showed activity only against Staphylococcus aureus [128].The antimicrobial properties of whole plants (extracted sequentially with different organic solvents) of Datura stramonium were studied against Escherichia coli, Staphylococcus aureus, Pseudomonas aeruginosa and the fungal strains Aspergillus flavus, Aspergillus niger, Fusarium culmorum and Rhizopus stolonifer. All the solvent extracts showed significant activity against all the tested microorganisms. Methanolic extract was the most active against all microorganisms, whereas all the extracts showed significant activity against $P$. aeruginosa. All the solvent extracts showed low MIC against A.niger [140]. The antibacterial and antifungal effects of benzene, chloroform and ethanol extracts of branches and leaves of Datura stramonium branches and leaves were studied against Enterobacter (clinical strain/PIMS), Micrococcus luteus (clinical strain/PIMS), Pseudomonas aeruginosa (clinical strain/PIMS), E.coli ATCC 25922, Staphylococcus aureus (clinical strain/PIMS) and Klebsiella pneumonia ATCC 700603. Datura stramonium chloroform extract produced maximum zone of inhibition $16 \pm 0.7 \mathrm{~mm}$ against Enterobacter, while it produced minimum zone of inhibition $(7 \pm 0.7 \mathrm{~mm})$ against $K$. pneumonia. Benzene extract of the plant exhibited maximum zone of inhibition $(15 \pm 0.7 \mathrm{~mm})$ against Enterobacter and $M$. luteus, while it produced minimum zone of inhibition $(9 \pm 0.3 \mathrm{~mm})$ against $S$. aureus and $K$. pneumonia, ethanol extract of Datura stramonium gave maximum zone of inhibition against $K$. pneumonia and minimum against $E$. coli. The MBC values revealed that benzene extract $(3.12 \mathrm{mg} / \mathrm{ml})$ was effective against $P$. aeruginosa while the same concentration of chloroform extract was very active against $S$. aureus, $P$. aeruginosa and $M$. luteus. All the extracts of Datura stramonium possessed significant antifungal activity against Saccharomyces cerevisiae, Aspergillus fumigatus and Aspergillus niger with maximum antifungal activity against $S$. cerevisiae and zone of inhibition was about $16 \pm 0.2 \mathrm{~mm}$ by ethanol extract, $15 \pm 0.3 \mathrm{~mm}$ by chloroform and $14 \pm 1.6 \mathrm{~mm}$ by benzene extract, while minimum antifungal activity was observed against $A$. niger [141].Datura stramonium extracts were investigated for their in vitro activity against Staphylococcus aurers ATCC25923, Methicillin-resistant S. aureus, Enterococcus sp., Escherichia colii ATCC25922, Enteroinvasive Escherichia coli and Pseudomonas aeruginosa. Datura stramonium leaf extracts exhibited a considerable antibacterial activity even at low concentrations. Methanolic leaf extracts showed the maximum inhibitory effect. The growth inhibition zone against Escherichia coli was $9.8 \mathrm{~mm}$ and against Staphylococcus aurers was $6.8 \mathrm{~mm}$ [142]. The antimicrobial effect of methanol extract from flower, seed and leaf of explant callus was studied against (Escherichia coli, Pseudomonas aeruginosa, Staphylococcus epidermidis and Bacillus subtilis) and four fungi strains (Fusarium semithectum, Fusarium colmorum, Ceratocystis ulmi and Rhizoctoina solani). The result showed that the methanol extract from green leaf explant callus possessed inhibitory effects on the growth of B. subtilis $(22 \mathrm{~mm})$ and S. epidermidis $(23 \mathrm{~mm})$. The methanolic extract of the vegetative root and the flower of Datura stramonium show an effective antifungal activity against Rhizoctonia solani fungus [143].Aqueous and organic solvent extracts of different parts of the plant were investigated for its anti-Vibrio cholera non-O1, and Vibrio parahaemolyticus using the disk diffusion method. The results revealed that Datura stramonium possessed a broad-spectrum vibriocidal effect [144].The antifungal effects of acetone extracts of Datura stramonium seeds were studied against selected phytopathogenic fungi (Penicillium janthinellum, Penicillium expansum, Aspergillus niger, Aspergillus parasiticus, Colletotrichum gloeosporioides, Fusarium oxysporum, Trichoderma harzianum, Phytophthora nicotiana, Pythium ultimum and Rhizoctonia solani). Extracts exhibited moderate to good antifungal activity,

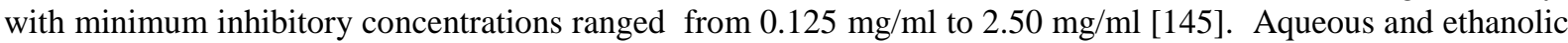
extracts of various parts of Datura stramonium were examined for their potential antimicrobial activity against pathogenic bacteria [Bacillus subtilis-2699, Escherichia coli-2803, Staphylococcus aureus-2602, Proteus vulgaris-2027, Salmonella typhi-2501; and pathogenic fungi such as Aspergillus flavus- 525, Aspergillus niger (local isolate), Candida albicans-3100 and Rhizopus stolonifer (local isolate)].The results showed that the ethanolic extracts were more potent than the aqueous extracts and leaf extract possessed better antimicrobial activity than stem, and root. Aqueous extract of te leaves showed antibacterial activity against Bacillus subtilis and Escherichia coli with zone of inhibition of 16 and $10 \mathrm{~mm}$ respectively, while ethanolic extracts of the leaves exerted antibacterial activity against Bacillus subtilis $(31 \mathrm{~mm})$, Escherichia coli $(18 \mathrm{~mm})$, Staphylococcus aureus (24mm), Salmonella typhi (10mm), Aspergillus flavus $(8 \mathrm{~mm})$ and Candida albicans $(10 \mathrm{~mm})$ [146].

\section{Insecticidal and repellent activities:}

The ethanolic extracts of leaves of Datura stramonium were evaluated for larvicidal and mosquito repellent activities against Aedes aegypti, Anopheles stephensi and Culex quinquefasciatus. The $\mathrm{LD}_{50}$ values for larvicidal activity were found to be $86.25,16.07$ and $6.25 \mathrm{ppm}$ against Aedes aegypti, Anopheles stephensi and Culex quinquefasciatus respectively. The ethanolic leaves extract of Datura stramonium provided complete protection time (Mosquito repellency) of 2.73, 71.66, 117.7 mins against these insects at 1\% concentration [147]. 


\section{Protective effect:}

The effectiveness of pretreatment with Datura seed extract (DSE) to increase the survival following organophosphate (dichlorvos) poisoning was evaluated in rats. Datura stramonium seeds were collected, crushed, and then heated in water to make a $2 \mathrm{mg} / \mathrm{ml}$ atropine solution (100 seeds contain approximately $6 \mathrm{mg}$ of atropine or $0.007 \mathrm{mg} / \mathrm{seed}$ ). Male rats were pretreated with $7.5 \mathrm{mg} / \mathrm{kg}$ DSE given as a single intraperitoneal injection 5 minutes prior to a subcutaneous injection of $25 \mathrm{mg} / \mathrm{kg}$ of dichlorvos. The endpoint was time to death recorded by a blinded observer. The 24-hour survival rate was $90 \%$ (95\% CI $=56 \%$ to $100 \%$ ) for the DSEpretreated group and $10 \%(95 \% \mathrm{CI}=0 \%$ to $45 \%)$ for the control group. A statistically significant longer survivalwas recorded for the Datura-treated animals $(\mathrm{p}=0.0002)$. Median survival time was 22 minutesand 30 seconds for the control group and greater than 24 hours for the DSE-pretreated group [148].The protective role of Datura stramonium leaves ethanolic extract against acute carbaryl toxicity was studied in rats. The animal with toxic dose of carbaryl showed mainly cholinergic effect, while those with toxic dose of Datura stramonium extract showed mainly anticholinergic effect symptom. The result of isobolographic analysis showed that the sort of interaction was highly antagonism. There was increase in the combined $\mathrm{LD}_{50}$ of carbaryl and Datura stramoinum extract nearly double that of each one alone, this was due to high tropane alkaloids contents of Datura stramonium that abolish carbaryl cholinergic toxic effect by blocking the muscarinic receptors of parasympathetic nerve ending [149].

\section{Analgesic effects:}

The analgesic effect of alcoholic Datura seed extract was evaluated in acute and chronic pain using hot plate and formalin tests. The extract when intraperitonealy administered to the animals, they, dose dependently, alleviated the pain, and $\mathrm{ED}_{50}$ was 25 and $50 \mathrm{mg} / \mathrm{kg}$ in hot plate and formalin tests, respectively [150].

\section{Antioxidant effect:}

The antioxidant activity of the plant extracts was assessed on the basis of the free radical scavenging effect, using modified DPPH method. Datura stramonium leaf extracts exhibited potent antioxidant property [142].

\section{Side effects and toxicity:}

The plant contraindicated in glaucoma, suspicion of glaucoma, paralytic ileus, pyloric stenosis, enlarged prostate, tachycardic arrhythmias and acute pulmonary edema [123].Exposure of the foetus to Datura stramonium when a mother used it for asthma, could resulted in permanent damage to the foetus. Therefore Datura stramonium containing herbal remedy should be used with caution during pregnancy [151].The calculated median lethal dose $\left(\mathrm{LD}_{50}\right)$ of the ethanolic extract of Datura stramonium leaves was $3185.25 \mathrm{mg} / \mathrm{kg}$ bw in rats [149]. Diets containing 0.5, 1.58 and 5.0\% Datura stramonium seed were fed to male and female rats in a 90-day subchronic toxicity study. Datura stramonium fed animals showed decreased body-weight gain, serum albumin and serum calcium, increased relative liver and testes weights, serum alkaline phosphatase and blood urea nitrogen. Female rats showed more marked responses to Datura stramonium seed than did males. In addition to the effects seen in both sexes, the females developed decreased serum total protein and cholesterol, and increased serum glutamic-pyruvic transaminase, chloride, red blood cell count, haemoglobin concentration and packed red cell volume. No histological lesions were associated with ingestion of Datura stramonium seed at $5.0 \%$. The authors concluded that Datura stramonium seed at concentrations of $0.5 \%$ or more in the diet produced adverse physiological changes in rats [152].The plant is a hallucinogenic plant, all parts of the plant can cause severe anticholinergic reactions that may lead to deathin human [153]. The whole plant, particularly the foliage \& seeds was toxic. It produced anticolinergic symptoms as a result of inhibition of central and peripheral cholinergic neurotransmission. Intoxicated patient usually presented with dry skin and mucus membranes, mydriasis with loss of accommodation that causes blurred vision and photophobia, altered mental status, hyperpyrexia, flushing, sinus tachycardia, urinary retention, myoclonic jerking, ataxia, impaired shortterm memory, disorientation, confusion, hallucinations, psychosis, agitated delirium, seizures, coma, respiratory failure and cardiovascular collapse [154-156]. Because of the central nervous system effects of the belladonna alkaloids, the patient may be agitated, combative, confused, and disoriented. Initial intervention focuses on addressing those issues that protect the patient and their caregivers. In severe cases, physostigmine, a cholinesterase inhibitor, should be used to reverse anticholinergic toxicity. Physostigmine should be given intravenously to an adult in a dose of $0.5-2.0 \mathrm{mg}$ at a rate of no more than $1 \mathrm{mg} / \mathrm{min}$; a second dose may be administered if necessary. Children should receive $0.02 \mathrm{mg} / \mathrm{kg}$ intravenously and the rate should not exceed 0.5 $\mathrm{mg} / \mathrm{min}$ [156].Lethal dosages for adults starting at $100 \mathrm{mg}$ atropine ( 15 to $100 \mathrm{~g}$ of the leaf, 15 to $25 \mathrm{~g}$ of the seed, considerably less for children) [123]. 
Dose:

60-185 mg powder of leaf and 60-120 mg powder of seed [157].

\section{CONCLUSION}

The current review discuss the chemical constituents and pharmacological effects of Datura fastuosa and Datura stramonium to be utilize for many therapeutic purposes as a results of wide pharmacological activities.

\section{REFERENCES}

[1] Davidson-Hunt I. Ecological ethnobotany: stumbling toward new practices and paradigms. MASA J 2000; 16: 1-13.

[2] Al-Snafi AE. Therapeutic properties of medicinal plants: a review of their detoxification capacity and protective effects (part 1). Asian Journal of Pharmaceutical Science \& Technology 2015; 5(4): 257-270. http://www.ajpst.com/File_Folder/257-270(ajpst).pdf

[3] Al-Snafi AE. Therapeutic properties of medicinal plants: a review of plants with hypolipidemic, hemostatic, fibrinolytic and anticoagulant effects (part 1). Asian Journal of Pharmaceutical Science \& Technology 2015; 5(4): 271-284. http://www.ajpst.com/File_Folder/271-284(ajpst).pdf

[4] Al-Snafi AE. Therapeutic properties of medicinal plants: a review of their effect on reproductive systems (part 1). Ind J of Pharm Sci \& Res 2015; 5(4): 240-248. http://www.ijpsrjournal.com/File_Folder/240248.pdf

[5] Al-Snafi AE. Therapeutic properties of medicinal plants: a review of their gastro-intestinal effects (part 1). Ind J of Pharm Sci \& Res 2015; 5(4): 220-232. http://www.ijpsrjournal.com/File_Folder/220232(ijpsr).pdf

[6] Al-Snafi AE. Therapeutic properties of medicinal plants: a review of their antiparasitic, antiprotozoal, molluscicidal and insecticidal activity (part 1). J of Pharmaceutical Biology 2015; 5(3): 203-217. www.jpbjournal.com/doi/OThrYWxhaTE0Nzg1MjM2OQ==

[7] Al-Snafi AE. Therapeutic properties of medicinal plants: a review of plants with antidiabetic effects (part 1). $\mathrm{J} \quad$ of $\quad$ Pharmaceutical $\quad$ Biology 2015; $218-229$. jpbjournal.com/doi/OTlrYWxhaTE0Nzg1MjM2OQ==

[8] Al-Snafi AE. A review on Dodonaea viscosa: A potential medicinal plant. IOSR Journal of Pharmacy 2017; 7(2): 10-21. http://www.iosrphr.org/papers/v7i2V1/B0702011021.pdf

[9] Al-Snafi AE. The pharmacology and medical importance of Dolichos lablab (Lablab purpureus)- A review. IOSR Journal of Pharmacy 2017; http://www.iosrphr.org/papers/v7i2V1/C0702012230.pdf

[10] Al-Snafi AE. Pharmacological and therapeutic importance of Desmostachya bipinnata- A review. Indo Am J P Sci 2017; 4(01): 60-66. http://iajps.com/pdf/january2017/9.Ali\%20Esmail\%20AlSnafi,IAJPS\%202017,4\%20(01),60-66.pdf

[11] Al-Snafi AE. Chemical constituents and pharmacological effects of Eryngium creticum- A review. Indo Am J P Sci 2017; 4(01): 67-73. http://iajps.com/pdf/january2017/10.\%20Ali\%20Esmail\%20AlSnafi,IAJPS\%202017,\%20(01),\%2067-73.pdf

[12] Al-Snafi AE. Cardiovascular effects of Carthamus tinctorius: A mini-review. Asian Journal of Pharmaceutical Research 2015; 5(3): 199-209. http://www.ajprjournal.com/zip.php?file=File_Folder/199207(ajpr).pdf\&id=163\&quat=5.

[13] Al-Snafi AE. Therapeutic properties of medicinal plants: a review of their immunological effects (part 1). Asian Journal of Pharmaceutical Research 2015; 5(3): 208-216. http://www.ajprjournal.com/zip.php?file=File_Folder/208-216(ajpr).pdf\&id=164\&quat=5.

[14] Al-Snafi AE. Therapeutic properties of medicinal plants: a review of their antibacterial activity (part 1). International Journal of Pharmacology and Toxicology 2015; 6(3): 137-158. http://www.ijptjournal.com/File_Folder/137-158(ijpt).pdf

[15] Al-Snafi AE. The pharmacology of Equisetum arvense- A review. IOSR Journal of Pharmacy 2017; 7(2): 31-42. http://www.iosrphr.org/papers/v7i2V1/D0702013142.pdf

[16] Al-Snafi AE. Therapeutic properties of medicinal plants: a review of their respiratory effects ( part 1). International Journal of Pharmacological Screening Methods 2015; 5(2):64-71. https://www.academia.edu/23041775/THERAPEUTIC_PROPERTIES_OF_MEDICINAL_PLANTS_A_ REVIEW_OF_THEIR_RESPIRATORY_EFFECTS_PART_1

[17] Al-Snafi AE. Therapeutic properties of medicinal plants: a review of their antiviral activity (part 1). International Journal of Pharmacological Screening Methods 2015; 5(2): 72-79. https://www.academia.edu/23041827/THERAPEUTIC_PROPERTIES_OF_MEDICINAL_PLANTS_A_ REVIEW_OF_THEIR_ANTIVIRAL_ACTIVITY_PART_1 
[18] Al-Snafi AE. Therapeutic properties of medicinal plants: a review of plants with cardiovascular effects (part 1). Int J of Pharmacology \& Toxicology 2015; 5(3): 163-176. http://ijpt.org/File_Folder/163176(ijptorg).pdf

[19] Al-Snafi AE. Therapeutic properties of medicinal plants: a review of medicinal plants with central nervous effects (part 1). Int J of Pharmacology \& Toxicology 2015; 5(3): 177-192. http://ijpt.org/File_Folder/177192(ijptorg).pdf

[20] Al-Snafi AE. Medicinal plants with anti-urolithiatic effects (part1). Int J of Pharmacy 2015; 5(2): 98-103. http://www.ijpjournal.org/File_Folder/98-103.pdf

[21] Al-Snafi AE. Therapeutic properties of medicinal plants: a review of plants affected smooth muscles functions (part 1). Int $J$ of Pharmacy 2015; 5(2): 90-97. https://www.academia.edu/23044464/THERAPEUTIC_PROPERTIES_OF_MEDICINAL_PLANTS_A_ REVIEW_OF_PLANTS_AFFECTED_SMOOTH_MUSCLES_FUNCTIONS_PART_1

[22] Al-Snafi AE. Clinically tested medicinal plant: A review (Part 1). SMU Medical Journal 2016; 3(1): 99128.

[23] Al-Snafi AE. Medicinal plants possessed anti-inflammatory antipyretic and analgesic activities (part 2)plant based review. Sch Acad J Pharm 2016; 5(5): 142-158. http://saspublisher.com/wpcontent/uploads/2016/06/SAJP-55142-158.pdf

[24] Al-Snafi AE. Medicinal plants affected reproductive systems (part 2) - plant based review. Sch Acad J Pharm 2016; 5(5): 159-174. http://saspublisher.com/wp-content/uploads/2016/06/SAJP-55159-174.pdf

[25] Al-Snafi AE. Medicinal plants with anticancer effects (part 2)- plant based review. Sch Acad J Pharm 2016; 5(5): 175-193. http://saspublisher.com/wp-content/uploads/2016/06/SAJP-55175-193.pdf

[26] Al-Snafi AE. Antiparasitic, antiprotozoal, molluscicidal and insecticidal activity of medicinal plants (part 2) - plant based review. Sch Acad J Pharm 2016; 5(6): 194-207. http://saspublisher.com/wpcontent/uploads/2016/07/SAJP-56194-207.pdf

[27] Al-Snafi AE. Medicinal plants with antidiabetic effects (part 2): plant based review. IOSR Journal of Pharmacy 2016; 6(7): 49-61. http://www.iosrphr.org/papers/v6i7V2/F06724961.pdf

[28] Al-Snafi AE. Medicinal plants with antioxidant and free radical scavenging effects (part 2): plant based $\begin{array}{llllll}\text { review. IOSR Journal of } & \text { Pharmacy }\end{array}$ http://www.iosrphr.org/papers/v6i7V2/G06726282.pdf

[29] Al-Snafi AE. Medicinal plants with antimicrobial activities (part 2): Plant based review. Sch Acad J Pharm 2016; 5(6): 208-239. http://saspublisher.com/wp-content/uploads/2016/07/SAJP-56208-239.pdf

[30] Al-Snafi AE. Medicinal plants with cardiovascular effects (part 2): plant based review. IOSR Journal of Pharmacy 2016; 6(7): 43-62. http://www.iosrphr.org/papers/v6i7V3/E067034362.pdf

[31] Al-Snafi AE. Detoxification capacity and protective effects of medicinal plants (part 2): plant based review. IOSR Journal of Pharmacy http://www.iosrphr.org/papers/v6i7V3/F067036384.pdf

[32] Al-Snafi AE. Beneficial medicinal plants in digestive system disorders (part 2): plant based review. IOSR Journal of Pharmacy 2016; 6(7): 85-92. http://www.iosrphr.org/papers/v6i7V3/G067038592.pdf

[33] Al-Snafi AE. A review of medicinal plants with broncho-dilatory effect-Part 1. Scholars Academic Journal of Pharmacy, 2015; 5(7): 297-304. http://saspublisher.com/wp-content/uploads/2016/08/SAJP57297-304.pdf

[34] Al-Snafi AE. Medicinal plants with central nervous effects (part 2): plant based review. IOSR Journal of Pharmacy 2016; 6(8): 52-75. http://www.iosrphr.org/papers/v6i8V1/G068015275.pdf

[35] Al-Snafi AE. Immunological effects of medicinal plants: A review (part 2). Immun Endoc \& Metab Agents in Med Chem 2016; 16(2): 100-121. http://www.eurekaselect.com/146338

[36] Al-Snafi AE. Medicinal plants affected male and female fertility (part 1)- A review. IOSR Journal of Pharmacy 2016; 6(10): 11-26. www.iosrphr.org/papers/v6i10V3/C0610031126.pdf

[37] Al-Snafi AE. Antiparasitic effects of medicinal plants (part 1)- A review. IOSR Journal of Pharmacy 2016; 6(10): 51-66. http://www.iosrphr.org/papers/v6i10V3/H0610035166.pdf

[38] Al-Snafi AE. Antimicrobial effects of medicinal plants (part 3): plant based review. IOSR Journal of Pharmacy 2016; 6(10): 67-92. http://www.iosrphr.org/papers/v6i10V3/I0610036792.pdf.

[39] Al-Snafi AE. Chemical constituents and pharmacological effects of Cynodon dactylon- A review. IOSR Journal of Pharmacy 2016; 6(7): 17-31. http://www.iosrphr.org/papers/v6i7V2/D06721731.pdf

[40] Al-Snafi AE. A review on Cyperus rotundus A potential medicinal plant. IOSR Journal Of Pharmacy 2016; 6(7): 32-48. http://www.iosrphr.org/papers/v6i7V2/E06723248.pdf

[41] Al-Snafi AE. The pharmacological importance of Antirrhinum majus - A review. Asian J of Pharm Sci \& Tech 2015; 5(4): 313-320. http://www.ajpst.com/File_Folder/313-320.pdf

[42] Al-Snafi AE. The chemical constituents and pharmacological importance of Celosia cristata - A review. J of Pharm Biology 2015; 5(4): 254-261. 
[43] Al-Snafi AE. The pharmacological importance of Centaurea cyanus- A review. Int J of Pharm Rev \& Res 2015; 5(4): 379-384. http://www.ijprr.com/File_Folder/379-384.pdf

[44] Al-Snafi AE. The chemical constituents and pharmacological importance of Chrozophora tinctoria. Int $\mathbf{J}$ of Pharm Rev \& Res 2015; 5(4): 391-396. http://www.ijprr.com/File_Folder/391-396.pdf

[45] Al-Snafi AE. Chemical constituents and pharmacological importance of Agropyron repens - A review. Research Journal of Pharmacology and Toxicology 2015; 1 (2): 37-41. http://asdpub.com/index.php/rjpt/article/view/244/156

[46] Al-Snafi AE. Chemical constituents and pharmacological effects of Citrullus colocynthis - A review. IOSR Journal of Pharmacy 2016; 6(3): 57-67. http://www.iosrphr.org/papers/v6i3/F0635767.pdf

[47] Al-Snafi AE. Medical importance of Cichorium intybus - A review . IOSR Journal of Pharmacy 2016; 6(3): 41-56. http://www.iosrphr.org/papers/v6i3/E0634156.pdf

[48] Al-Snafi AE. Pharmacological importance of Clitoria ternatea - A review. IOSR Journal of Pharmacy 2016; 6(3): 68-83. http://www.iosrphr.org/papers/v6i3/G0636883.pdf

[49] Al-Snafi AE. The medical Importance of Cicer arietinum - A review. IOSR Journal of Pharmacy 2016; 6(3): 29-40. http://www.iosrphr.org/papers/v6i3/D0632940.pdf

[50] Al-Snafi AE. Medical importance of Anthemis nobilis ( Chamaemelum nobilis)- A review. Asian Journal of Pharmaceutical Science \& Technology 2016; 6(2): 89-95. http://www.ajpst.com/File_Folder/8995(ajpst).pdf

[51] Al-Snafi AE. Adonis aestivalis: pharmacological and toxicological activities- A revew. Asian Journal of Pharmaceutical Science \& Technology 2016; 6(2): 96-102. http://www.ajpst.com/File_Folder/96102(ajpst).pdf

[52] Al-Snafi AE. The pharmacological activities of Cuminum cyminum - A review. IOSR Journal of Pharmacy 2016; 6(6): 46-65. http://www.iosrphr.org/papers/v6i6V2/G066024665.pdf

[53] Al-Snafi AE. Medical importance of Cupressus sempervirens- A review. IOSR Journal of Pharmacy 2016; 6(6): 66-76. http://www.iosrphr.org/papers/v6i6V2/H066026676.pdf

[54] Al-Snafi AE. The contents and pharmacology of Crotalaria juncea- A review. IOSR Journal of Pharmacy 2016; 6(6): 77-86. http://www.iosrphr.org/papers/v6i6V2/I066027786.pdf

[55] Al-Snafi AE. The medical importance of Cydonia oblonga- A review. IOSR Journal of Pharmacy 2016; 6(6): 87-99. http://www.iosrphr.org/papers/v6i6V2/J066028799.pdf

[56] Al-Snafi AE. The pharmacology of Crocus sativus- A review. IOSR Journal of Pharmacy 2016; 6(6): 838. http://www.iosrphr.org/papers/v6i6V3/C06630838.pdf

[57] Al-Snafi AE. The chemical constituents and therapeutic importance of Cressa cretica-A review . IOSR Journal of Pharmacy 2016; 6(6): 39-46. http://www.iosrphr.org/papers/v6i6V3/D06633946.pdf

[58] Al-Snafi AE. The Pharmacological and therapeutic importance of Cordia myxa- A review. IOSR Journal of Pharmacy 2016; 6(6): 47-57. http://www.iosrphr.org/papers/v6i6V3/E06634757.pdf

[59] Al-Snafi AE. The contents and pharmacological importance of Corchorus capsularis- A review. IOSR Journal of Pharmacy 2016; 6(6): 58-63. http://www.iosrphr.org/papers/v6i6V3/F06635863.pdf

[60] Al-Snafi AE. The chemical constituents and pharmacological effects of Convolvulus arvensis and Convolvulus scammonia - A review. IOSR Journal of Pharmacy 2016; 6(6): 64-75. http://www.iosrphr.org/papers/v6i6V3/G06636475.pdf

[61] Al-Snafi AE. A review on chemical constituents and pharmacological activities of Coriandrum sativum. IOSR Journal of Pharmacy 2016; 6(7): 17-42. http://www.iosrphr.org/papers/v6i7V3/D067031742.pdf

[62] Al-Snafi AE. Pharmacology and toxicology of Conium maculatum- A review. The Pharmaceutical and Chemical Journal 2016; 3(2):136-142. http://tpcj.org/download/vol-3-iss-2-2016/TPCJ2016-03-02-136142.pdf

[63] Al-Snafi AE. The constituents and pharmacology of Cnicus benedictus- A review. The Pharmaceutical and Chemical Journal 2016; 3(2):129-135. http://tpcj.org/download/vol-3-iss-2-2016/TPCJ2016-03-02129-135.pdf

[64] Al-Snafi AE. Medicinal importance of Colchicum candidum- A review. The Pharmaceutical and Chemical Journal 2016; 3(2):111-117. http://tpcj.org/download/vol-3-iss-2-2016/TPCJ2016-03-02-111117.pdf

[65] Al-Snafi AE. Nutritional value and pharmacological importance of citrus species grown in Iraq. IOSR Journal of Pharmacy 2016; 6(8): 76-108. http://www.iosrphr.org/papers/v6i8V1/H0680176108.pdf

[66] Al-Snafi AE. The pharmacological and toxicological effects of Coronilla varia and Coronilla scorpioides: A review. The Pharmaceutical and Chemical Journal 2016; 3(2): 105-114. http://tpcj.org/download/vol-3-iss-3-2016/TPCJ2016-03-03-105-114.pdf

[67] Al-Snafi AE. Pharmacological activities of Cotoneaster racemiflorus - A review. The Pharmaceutical and Chemical Journal 2016, 3(2):98-104. http://tpcj.org/download/vol-3-iss-3-2016/TPCJ2016-03-03-98104.pdf 
[68] Al-Snafi AE. The constituents and pharmacology of Corchorus aestuans: A review. The Pharmaceutical and Chemical Journal 2016; 3(4):208-214. http://tpcj.org/download/vol-3-iss-4-2016/TPCJ2016-03-04208-214.pdf

[69] Al-Snafi AE. The chemical constituents and pharmacological activities of Cymbopagon schoenanthus: A review. Chemistry Research Journal 2016; 1(5):53-61. http://chemrj.org/download/vol-1-iss-52016/chemrj-2016-01-05-53-61.pdf

[70] Al-Snafi AE. Traditional uses, constituents and pharmacological effects of Cuscuta planiflora. The Pharmaceutical and Chemical Journal 2016; 3(4): 215-219. http://tpcj.org/download/vol-3-iss-42016/TPCJ2016-03-04-215-219.pdf

[71] The plant list, a working list of all plant species, http://www.theplantlist.org/tpl/ record/kew-2757816.

[72] Ganesh S, Radha R and Jayshree N. A review on phytochemical and pharmacological status of Datura fastuosa linn. International Journal of Multidisciplinary Research and Development 2015; 2(4): 602-605.

[73] U.S. National Plant Germplasm System, Datura metel, https://npgsweb.ars-grin.gov/ gringlobal/taxonomydetail.aspx?id=13315

[74] Chinese plant names, Datura metel, http: //www .efloras .org/ florataxon .aspx? flora_id $=3 \&$ taxon_id=200020519.

[75] Parrotta JA. Healing plants of India. CABI Publishing, Wallingford, UK and New York 2001:917.

[76] The ayurvedic pharmacopoeia of India, part I, Volume V. Government of India Ministry of Health and Family Welfare Dept of Ayush, Delhi, 2008 30, 51.

[77] Ratan L, Meenu B, Anju D and Arun N. Morpo- anatomical and physicochemical studies of dried seeds of Datura fastuosa Linn. . IRJP 2011; 2 (3): 208-212.

[78] Indra Rai, Bachheti RK, Joshi A and Pandey DP. Physicochemical properties and elemental analysis of some non-cultivated seed oils collected from Garhwal region, Uttarakhand (India). IJCRGG 2013; 5 (1): 232-236.

[79] Xue J, Sun Y, Wei Q, Wang C, Yang B, Kuang H and Wang Q. Chemical composition and cytotoxicity of the essential oil from different parts of Datura metel L. Nat Prod Res 2015; 29:1-3.

[80] European Food Safety authority. Tropane alkaloids (from Datura sp.) as undesirable substances in animal feed. The EFSA Journal 2008; 691: 1-55.

[81] Afsharypuour S, mostajeran A and Mokhtany R. Variation of scopolamine and atropine in different parts of D. metel during development plant. Medicine 1995; 61: 383-384.

[82] Manickam M, Sinha-Bagchi A, Sinha Sc, Gupta M and Ray AB. Withanolides of Datura fastuosa leaves. Phytocemistry 1993; 34(3): 868-870.

[83] Yang B, Wang Q, Xia Y, Feng W and Kuang H. Withanolide compounds from the flower of Datura metel L. Helvetica Chimica Acta 2007; 90(8): 1522-1528.

[84] Yang BY, Guo R, Li T,Lin Y, Wang C, Shu Z, Wang Z, Zhang J, Xia Y, Jiang H, Wang Q and Kuang H. Five withanolides from the Leaves of Datura metel L. and their inhibitory effects on nitric oxide production. Molecules 2014; 19: 4548-4559.

[85] Okwu DE and Igara EC. Isolation, characterization and antibacterial activity of alkaloid from D. mete Linn leaves African Journal of Pharm and Pharmacology 2009; 3(5): 277 - 781.

[86] Khaleque A, Akm MR, Ismail KM, Sadrul Amin M and Kiamuddin M. Investigations on Datura fastuosa solanaceae part 5: isolation of fastusine scopolamine and beta sitosterol from the pericarp fruit shell. Bangladesh Journal of Scientific and Industrial Research 1974; 9 (1/2): 79-81.

[87] Pan Y, Wang X and Hu X. Cytotoxic withanolides from the flowers of Datura metel. J Nat Prod 2007; 70(7): 1127-1132.

[88] Yang BY, Guo R, Li T, Wu JJ, Zhang J, Liu Y, Wang QH and Kuang HX. New anti-inflammatory withanolides from the leaves of Datura metel L. Steroids 2014; 87: 26-34.

[89] Anu Kiruthika K and Sornaraj R. Screening of bioactive components of the flower Datura metel using the GC-MS technology. International Journal of PharmTech Research 2011;3(4): 2025-2028.

[90] Kuang HX, Yang BY, Xia YG and Feng WS. Chemical constituents from the flower of Datura metel L. Arch Pharm Res 2008; 31(9): 1094-1097.

[91] Han XL, Wang H, Zhang ZH, Tan Y and Wang JH. Study on Chemical Constituents in Seeds of Datura metel from Xinjiang. Hong Yao Cai 2015; 38(8): 1646-1648.

[92] Roy S, Pawar S and Chowdhary A. Evaluation of in vitro cytotoxic and antioxidant activity of Datura metel Linn. and Cynodon dactylon Linn. extracts. Pharmacognosy Res 2016; 8(2):123-127.

[93] Dhiman A, La R, Bhan M, Dhiman B and Hooda A. Plebeian assessment of anti microbial and in vitro antioxidant zest of D. fastuosa L. seeds. Journal of Pharmaceutical and Scientific Innovation 2012; 1(4); 49-53. 
[94] Salma Sk, Lalitha Ch, Venkatarameshwar K, Jagadeesh Babu S and Vijitha M. Evaluation of antipathogenic effect of Datura metal Linn. leaf extract on enterobacter species. AJCPR 2015; 3(2): 306309.

[95] Rajesh and Sharma GL. Studies on antimycotic properties of Datura metel. J Ethnopharmacol 2002; 80(2-3): 193-197.

[96] Dabur R, Ali M, Singh H, Gupta J and Sharma GL. A novel antifungal pyrrole derivative from Datura metel leaves. Pharmazie 2004; 59(7):568-570.

[97] Yamazaki Z and Tagaya I. Antiviral effects of atropine and caffeine. J Gen Virol 1980; 50:429-431.

[98] Alarcon B, Gonzalez ME and Carrasco L. Antiherpesvirus action of atropine. Antimicrob Agents Chemother 1984; 26(5):702-706.

[99] Singh V and Singh R. Effect of Datura metel seed methanol extract and its fractions on the biology and ovipositional behaviour of Helicoverpa armigera. J Med and Aro Plant Sci 2008; 30(2): 157-163.

[100] Nivedhitah S, Gopinath M, Muthusamy P and Rao KM. Studies on anti inflammatory activity of root extracts of D. fastuosa L. Journal of pharmacy Research 2010; 3(11): 2686 -2688.

[101] Abena AA, Miguel LM, Mouanga A, Hondi Assah T and Diatewa M. Evaluation of analgesic effect of D. fastuosa L leaves and seed extracts. Fitoterapia 2003; 74(5): 486-488.

[102] Abena AA, Miguel LM, Mouanga A, Ouamba JM, Sianard DF, Thiebolt MH, Hondi-Assah TC and Diatewa M. Neuropsychopharmacological effects of leaves and seeds extracts of Datura fastuosa. Biotechnology 2004; 3(2): 109-113.

[103] Prabhakar E. Kumar NVN. Spasmogenic effect of D.metel root extract on rat uterus and rectum smooth muscles. Phytotherapy Research 1994; 8(1):52-54.

[104] Babalola SA, Sulaiman MM, Hassan AZ and Adawa DAY. Evaluation of crude methanolic seed extract of of Datura metel L : as a potential oral anasthetic in dogs Veterinary Research 2013; 6(5-6): 115-119.

[105] Babalola SA, Suleiman MM, Hassan AZ and Adawa DAY. Evaluation of Datura metel L seed extract as a sedative/hypnotic: a priliminary study. J Vet Adv 2015; 5(4): 857-862.

[106] Etibor TA, Ajibola MI, Buhari MO, Safiriyu AA, Akinola OB and Caxton-Martins EA. Datura metel administration distorts medial prefrontal cortex histology of wistar rats. World Journal of Neuroscience 2015; 5: 282-291.

[107] Deepa M, Sugitha N, Mythili S and Sathiavelu A. Antioxidant activity and phytochemical analysis of Datura metel. Int J Drug Dev \& Res 2014; 6(4): 280-285.

[108] Bellila A, Tremblay C, Pichette A, Marzouk B, Mshvildadze V, Lavoie S and Legault J. Cytotoxic activity of withanolides isolated from Tunisian Datura metel L. Phytochemistry 2011; 72(16): 2031-2036.

[109] Anitha Vimal.S and Suseela L. In vitro antioxidant activity and wound healing activity of the alcoholic extract of the alcoholic extract of the ariel parts of Datura fastuosa Linn. Journal of Pharmacy Research $2010 ; 2(8): 1176-1179$.

[110] Krishna Murthy B, Nammi S, Kota MK, Krishna Rao RV, Koteswara Rao N and Annapurna A. Evaluation of hypoglycemic and antihyperglycemic effects of Datura metel (Linn.) seeds in normal and alloxan-induced diabetic rats. J Ethnopharmacol 2004; 91(1):95-98.

[111] Umamaheswari M, Asok Kumar K, Somasundaram A, Sivashanmugam T, Subhadradevi V and Ravi TK. Xanthine oxidase inhibitory activity of some Indian medical plants. J Ethnopharmacol 2007; 109(3): 547-551.

[112] Pandiarajan G, Govindaraj R, Makesh Kumar B and Sankarasivaraman K. Antifertility activity in the acetone extracts of Datura metel, L seeds on female mouse. J Pharmacogenomics Pharmacoproteomics 2012; 3: 111.

[113] Al-Mailay HKA. The effect Datura fastuolsa L. alcohol extract on the fertility of white rats males. J AlQadisiyah for Pure Sciences 2008; 13(3): 1-11.

[114] Kam PCA and Liew S. Traditional Chinese herbal medicine and anesthesia. Anaesthesia 2002; 57:10831089.

[115] Ko RJ. Causes, Epidemiology, and clinical evaluation of suspected herbal poisoning. Clin Toxicol 1999; 37(6):697-708.

[116] Tijani AA, Adeniyi DT and Adekoni DA. Datura metel is deleterious to the visiual cortex of adult Wistar rats. Advances in Applied Science Research 2012;3(2):944-949.

[117] Damilare AA, Tijani AA and Ghazal OK. some effects of the aquoes leaf extract of Datura metel on the frontal cortex of adult rats (Rattus nurvegicus). Eur J Anat 2010; 14 (2): 83-89.

[118] Bauzidi A, Mahdeb N and Kara N. Toxicity studies of alkaloids of seeds of Datura stramonium and synthesis alkaloids in male rats. J Med Plants Res 2011; 5 (15): 342-343.

[119] U.S. National Plant Germplasm System, Datura stramonium L., https://npgsweb.ars-grin.gov/ gringlobal/taxonomydetail.aspx?13323 
[120] The plant list, a working list of all plant species. Datura stramonium, http://www.theplantlist .org/ tpl1.1/record/kew-2757848

[121] Gaire BP and Subedi L. A review on the pharmacological and toxicological aspects of Datura stramonium L. Journal of Integrative Medicine 2013; 11(2) :73-79.

[122] Bayih T. Synergistic bio-eficacy of insecticidal plants against bean bruchids (Zabrotes subfasciatus: Coleoptera) a major storage pests of common bean (Phaseolus vulgaris L.) in central rift valley of Ethiopia. MSc thesis, Department of Biology, School of Graduate Studies, Haramaya University, 2014.

[123] PDR for Herbal Medicines. Medical Economics Company, Inc. at Montvale, 2000: 436-437.

[124] Williams DG. Larvicidal potential of the leaf extract of Datura stramonium and Occimum gratissimum against Culex quinquefasciatus mosquito species. MSc thesis, Faculty of Science, Amadu Bello University- Zaria 2013.

[125] Rajbhandari KR Ethnobotany of Nepal. Kathmandu: Kishor Offset Press Private Limited, 2001: 142-143.

[126] Egharevba RKA and Ikhatua MI. Ethno-medical uses of plants in the treatment of various skin diseases in Ovia North East, Edo State, Nigeria. Res J Agric Biol Sci 2008; 4(1): 58-64.

[127] Kirtikar KR and Basu BD. Indian medicinal plants. $2^{\text {nd }}$ ed. Volume III. Dehradun: International Book Distributors 1999: 1783-1787.

[128] Shagal MH, Modibbo UU and Liman AB. Pharmacological justification for the ethnomedical use of Datura stramonium stem-bark extract in treatment of diseases caused by some pathogenic bacteria. Int Res Pharm Pharmacol 2012; 2(1): 16-19.

[129] Lewis OAM, Nieman E and Munz.A. Origin of amino acids in Datura stramonium seeds. Ann of Bot 1970; 34: 843-848.

[130] Robbers JE, Speedie MK and Tyler VE. Pharmacognosy and Pharmacobiotechnology. Williams and Wilkins, Philadelphia, 1996.

[131] Iranbakhsh A, Oshaghi MA and Majd A. Distribution of atropine and scopolamine in different organs and stages of development in Datura stramonium L. (Solanaceae). Structure and ultrastructure of biosynthesizing cells. Acta Biologica Cracovensia, Series Botanica 2006; 48(1): 13-18.

[132] Devi MR, Bawari M, Paul SB and Sharma GD. Neurotoxic and medicinal properties of Datura stramonium L. - Review. Assam University Journal of Science \& Technology Biological and Environmental Sciences 2011; 7(I): 139-144.

[133] Elisabetta M, Alessandra M, Ferri S and Comparini IB. Distribution of hyoscyamine and scopolamine in Datura stramonium. Fitoterapia 2001; 72(6) : 644-648.

[134] Sayyed A and Shah M. Phytochemistry, pharmacological and traditional uses of Datura stramonium L. review. Journal of Pharmacognosy and Phytochemistry 2014; 2 (5): 123-125.

[135] Berkov S, Zayed R and Doncheva T. Alkaloid patterns in some varieties of Datura stramonium. Fitoterapia 2006; 77 ( 3):179-182.

[136] You LX and Wang SJ. Chemical composition and allelopathic potential of the essential oil from Datura stramonium L. Advanced Materials Research 2011; 233-235:2472-2475.

[137] Li J, Lin B, Wang G, Gao H and Qin M. Chemical constituents of Datura stramonium seeds. Zhongguo Zhong Yao Za Zhi 2012; 37(3): 319-322.

[138] Peredery $\mathrm{O}$ and Persinger MA. Herbal treatment following post-seizure induction in rat by lithium pilocarpine: Scutellaria lateriflora (Skullcap), Gelsemium sempervirens (Gelsemium) and Datura stramonium (Jimson Weed) may prevent development of spontaneous seizures. Phytother Res 2004;18(9):700-705.

[139] Charpin D, Orehek J and Velardocchio JM. Bronchodilator effects of antiasthmatic cigarette smoke (Datura stramonium). Thorax 1979; 34(2): 259-261.

[140] Sharma RA, Sharma P and Yadav A. Antimicrobial screening of sequential extracts of Datura stramonium L. Int J Pharm Pharm Sci 2013; 5(2): 401-404.

[141] Gul H, Qaisrani RN, Khan MA, Hassan S and Younis N. Antibacterial and antifungal activity of different extracts of Datura stramonium (branches and leaves sample). Journal of Biotechnology and Pharmaceutical Research 2012; 3(9): 141-148.

[142] Sreenivasa S, Vinay K and Mohan NR. Phytochemical analysis, antibacterial and antioxidant activity of leaf extract of Datura stramonium. International Journal of Science Research 2012;1(2): 83-86.

[143] Iranbakhsh A, Ebadi M and Bayat M. The inhibitory effects of plant methanolic extract of Datura stramonium L. and leaf explant callus against bacteria and fungi. Global Veterinaria 2010; 4 (2): 149-155.

[144] Sharma A, Patel VK and Chaturvedi AN. Vibriocidal activity of certain medicinal plants used in Indian folklore medicine by tribals of Mahakoshal region of central India. Indian J Pharmacol 2009; 41(3): 129133. 
[145] Mdee LK, Masoko P and Eloff JN. The activity of extracts of seven common invasive plant species on fungal phytopathogens. South African Journal of Botany 2009; 75(2): 375-379.

[146] Gachande BD, Khillare EM. In vitro evaluation of Datura species for potential antimicrobial activity. Bioscience Discovery 2013; 4(1):78-81.

[147] Swathi S, Murugananthan G, Ghosh SK and Pradeep AS. Larvicidal and repellent activities of ethanolic extract of Datura stramonium leaves against mosquitoes. Inter J Pharmacogn Phytochem Res 2012; 4(1): 25-27.

[148] Bania TC, Chu J, Bailes D and O'Neill M. Jimson weed extract as a protective agent in severe organophosphate toxicity. Acad Emerg Med 2004;11(4):335-338.

[149] Al Ani KA and Abbas DA. The protective role of Datura stramonium leaves ethanolic extract against acute carbaryl toxicity in rats. Int J of Biomedical and Advance Res 2015; 6(05): 400-405.

[150] Khalili Najafabadi M and Atyabi SM. Evaluation of analgesic effect of Datura stramonium seed extract in hot plate and formalin tested on male rats. I. J Med and Arom Plants 2004; 20 (3): 309-322.

[151] Pretorius E and Marx J. Datura stramonium in asthma treatment and possible effects on prenatal development. Environ Toxicol Pharmacol. 2006; 21(3): 331-337.

[152] Dugan GM, Gumbmann MR and Friedman M. Toxicological evaluation of Jimson weed (Datura stramonium) seed. Food Chem Toxicol 1989; 27(8): 501-510.

[153] Diker D, Markovitz D, Rothman M and Sendovski U. Coma as a presenting sign of Datura stramonium seed tea poisoning. European J Internal Med 2007: 336-338.

[154] Alberto K, Claudia S, Ludmilla K and Arnon B. Toxic Delirium due to Datura stramonium. Israel Med Asso J 2001; 3: 538-539.

[155] Julyan M. Datura stramonium L. - Narcotic, anodyne or poison? International Journal of Humanities and Social Science 2014; 4(2): 177-185.

[156] Krenzelok EP. Aspects of datura poisoning and treatment. Clin Toxicol (Phila) 2010; 48(2): 104-110.

[157] Khare CP. Indian medicinal plants. Delhi: Rajkamal Electric Press 2007: 203. 